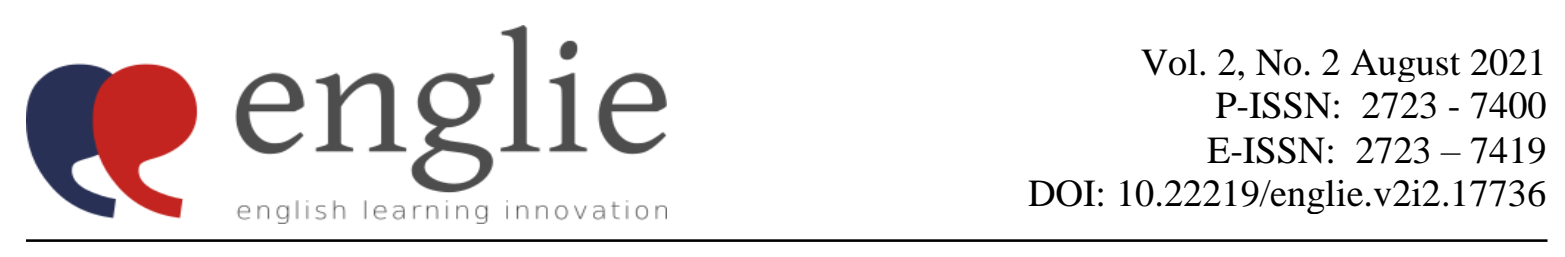

\title{
The Correlation between Silence Phenomenon and EFL Student Online Class
}

\author{
Zahrah Qurota' Ayu Nurrohmah \\ English Language Education Department, Universitas Muhammadiyah Malang, Indonesia
}

\begin{abstract}
Alimin Adi Waloyo
English Language Education Department, Universitas Muhammadiyah Malang, Indonesia

Corresponding author: aliminwaloyo@umm.ac.id
\end{abstract}

\begin{abstract}
In order to eliminate the spread of the Corona Virus, the students have been being required to study from homes either synchronously or asynchronously. It is commonly known as an online class. It has been being done to cut the spread of the COVID-19 virus. This new teaching approach needs EFL students to adjust their way of learning. Also, the online class creates some challenges, such as limited interaction, low motivation, internet connection issues, etc) for EFL learners in their learning process because teachers and students have less interaction. This situation is called a silence phenomenon. Due to this was a new type of issue in EFL teaching and less investigated research, the researchers conducted the study to investigate the factors and solutions of the silencing phenomenon faced by EFL students during an online class. This study employed a case study research method. The subjects of this study were ten students of English Language Education Department students, 2017 academic year at the University of Muhammadiyah Malang (UMM). The researcher collected the data through the interview technique. The interview was applied, so the researchers obtained rich and in-depth data. The finding of this study showed that students' active participation during online classes was very low. That low participation was caused by several aspects: individual, teacher, cultural, technological, and domestic. The students could implement various ways to minimize the students' reticence in the online class. This research hopefully provides different views to make teachers' online classes fun and interesting, so English learning can obtain optimal outcomes.
\end{abstract}

Keywords: EFL students, online class, silence phenomenon 


\section{INTRODUCTION}

COVID-19 pandemic has shifted many aspects of people's life because people have to do physical distancing as a crucial part to halt the spread of the virus. This is a deadly virus that can transmit so quickly if people are close to each other. During this condition, the government, health providers, and policymakers work together to fight against it (Gulati et al., 2020). Therefore, the national government requires educational activities in schools to do online learning. It is commonly known as virtual learning. Because of conditions and government policy, students are required to study from home through Learning Management System (LMS) or applications. This situation also applies to university students throughout Indonesia. This is done to cut the spread of the COVID-19 virus. To start the learning process during the COVID19 pandemic, students do not need to come to the class. The online class activity is carried out with the help of technology (Sun \& Chen, 2016). For instance, teachers will manage the class and instruct the teaching and learning activities using Google Classroom, Edmodo, or Schoology.

Therefore, they are needed to be responsive to adapt their teaching and learning management that can fit this new era of learning (Amin \& Sundari, 2020). This new situation requires teachers to be more creative and fun, so online learning can still be enjoyable for learners. More importantly, virtual class is a great way to combat this deadly pandemic because there will be physical contact that causes the spread of the virus. It must the application of teaching media, learning materials, and evaluation have to be adjusted to fit into the students' situation (Amin \& Sundari, 2020)

The government's policy for online learning is good so students still can study although they do not have to come to class. However, the policies issued cannot ensure that everything will run smoothly and properly (Abidah et al., 2020). Some learning issues might appear due to this new normal in the education context. In other words, the effect of the coronavirus on the educational world could make the class situation create some problems (Min, 2016). It is because teachers and students have less interaction. It can be said as a silent phenomenon.

In EFL classes, the silence class phenomenon is becoming a problem because students tend to be quiet (Zhouyuan, 2016). Students are still listening to their teachers' words, but they do not get involved in the learning process and expressing their ideas or thoughts. Silence is a condition in which someone does not make any sounds (Zhouyuan, 2016). It can be defined 
that silence is the activity of making no sound in a specific area. Juniati et al., (2018) state that silence is a phenomenon in which students do not talk or speak while they are in the classroom. Boredom, hopelessness, disinterest, are signs that can cause students' silence. It can be seen as a negative phenomenon because, in language learning, the interaction between teacher and students is very important (Wang, 2016). Without any active interaction among them, the learning outcomes will be hard to reach. This is going to be a serious problem because when learning outcomes are not reached, the teaching and learning process is failed. Considering the problem above, the researchers would like to explore the factors causing the silencing phenomenon in the EFL class.

Min (2016) in his study stated that to minimize the negative influence of the silencing phenomenon, both teachers and students should have any changes in the teaching and learning process. They have to create a new approach to cope with that problem. For example, designing the materials which focus on collaboration to create projects for English speaking skills development. It is undeniable that online learning creates the silencing phenomenon. However, it is also very flexible for project-based EFL learning. One of the benefits of online learning is that it is more flexible (Kuama, 2016). So, it is a great opportunity to let them improve their English effectively and efficiently because they can collaborate despite their geographical distances.

In the previous study, Choi (2015) identified the reasons why two Korean students tend to keep silent at U.S graduate programs class. Choi in his study explored the perception and the reasons Korean students tend to be silent in class. The results of the study showed that the reasons for that case are they were a lack of speaking proficiency relevant to academic work and it was the influence of Korean classroom manners, face-saving, and lack of background and content knowledge. It was clear that their low proficiency in English affected their silence in class.

Juniati et al., (2018) also investigated students' silence, especially at the university level. In this case, Juniati et al., (2018) wanted to know the reason and explore the solution from the lecturer to overcome the silencing phenomenon in the EFL speaking class. The results showed that the reasons that thirteen students were silent in the class were different. The reasons vary from personal low motivation to low English competence. Therefore, EFL teachers need to identify students' needs and wants to boost their motivation for learning English. Also, the teachers need to improvise with various teaching approaches by involving the use of technology as a part of English learning. 
Van Tuyen (2018) found three factors leading to the silent phenomenon. The first is because of the student's lack of confidence and knowledge. This aspect needs to get special attention, so it can be diminished gradually. The second is personal beliefs and different cultures. It is more contextual. Therefore, it might be easier to be overcome this one if the teachers teach them about various cultures and keep boosting their motivation. Lastly, it is the teacher's teaching method.

Furthermore, Harumi (2011) found three factors that could influence classroom silence: linguistics, psychological, and sociocultural factors. It means that EFL students do not get engaged in class because they know less about English or have low English competence, have issues related to their confidence and communication, and have a low understanding of social communication or collaboration among them. The other study conducted by Pranasti (2013) found two factors of the phenomenon; students' factor and teachers' methodology.

Several previous studies have identified that the silent phenomenon that occurs in the classroom is mainly due to three main factors which have nothing to do with the internet connection because they were conducted online. Baticulon et al., (2020) in their research found the five obstacles that can affect the student's performance in an online class. Technology, individual, domestic, institutional, and community. All of them contribute to be the factors that can affect the student's performance in the online class.

The previously mentioned studies investigated the factors of classroom silence in a faceto-face class. They found various findings. However, the researchers hardly found the silencing phenomenon caused by the online class. Therefore, the researchers studied this issue. Also, this study was conducted while virtual class is a compulsory classroom activity, so this study outcomes might be very beneficial for both EFL teachers and learners o eliminate the classroom online silence. The researchers focused on one important thing in the investigation. The study would attempt to identify the factors that would cause classroom silence in an online EFL class.

\section{METHOD}

This study employed a case study research method. The case study research was included as a type of qualitative research method (Starman, 2013). Ryan et al., (2009) highlighted that qualitative research is usually concerned with nature and phenomena. It means that this type of research would portray the real phenomenon in nature. The researchers used qualitative design in this study because the researchers wanted to explore the factors and the solutions of the 
silencing phenomenon. Students tend to be more silent during the online class, even the teacher asked them and already delivered the material comprehensively and clearly. This case led the researchers to find out more precisely why students were quiet during online English teaching and learning classroom activities.

The researchers applied proportional sampling in determining the subject. Proportional sampling is a sampling technique in which the researchers divided the population into subpopulations and then take a sample in each subpopulation (Salkind, 2010). To investigate the silencing phenomenon during online class, the subjects were ten English Language Education Department students, 2017 academic year at the University of Muhammadiyah Malang (UMM).

The researchers collect the data using the interview technique. The interview guide was used as the instrument in this study. Through the interview, the collected data were rich and comprehensive, so the findings would be more extensive. The researchers used the semistructured interview to gain the research subjects' views, thoughts, and opinions. Semistructured interviews are often used when researchers want to explore a topic and thoroughly understand their answers (Margaret C. Harrell; Melissa A. Bradley, 2009).

Virtual focus group discussions and web-based interviews via email, weblogs such as online open-ended question diaries, and internet message boards are some of the ways to get information via the internet (Creswell, 2003). Due to the improvement of virtual communication, virtual interviews using video call WhatsApp occurred in this study. It was applied because it was cost-effective, fast, and highly recommended due to social distancing policy. The interviews took 20-30 minutes in length. Online data collection is a standard format in qualitative research.

\section{FINDINGS AND DISCUSSION}

The data of this study were collected from the semi-structured interview to identify the factors causing classroom silence in an online EFL class. The results of this study were taken from a semi-structured interview with the EFL students of the English language education department of the University of Muhammadiyah Malang, 2017 academic year who joined the EFL online class. The pseudonyms FP1, FP2, FP3, FP4, FP5, MP6, MP7, MP8, MP9, MP10 were used instead of using the students' real names to keep the confidentiality of the students. 
The finding indicated that students' active participation during online classes was not much. Several factors are making the students having low classroom participation during an online English teaching and learning class. The researchers divided the factors based on the participant's answer into five categories.

\section{Individual factor}

Based on the students' responses to the interview, the individual factor is one of the factors causing classroom silence. The students often preferred silent rather than active to answer questions during online classes or ask questions about the material that has been given. Individual factors could be caused by students themselves, such as lack of self-confidence, fear of making mistakes, low English proficiency, and low motivation to learn.

"I rarely participate in an online class, because sometimes I still lack confidence when

I want to answer the question because I'm afraid to make a mistake and so on ....... because I feel less confident, then I better be quiet in class."

“...sometimes in the course, lecturer obligate the students to use only English to answer or ask the question, but I don't believe about my English abilities to answer, like the grammar of the sentence"

"...if there is someone that could answer it better, I just keep silent in class."

(MP7)

The students' responses indicate that they were not confident to engage or actively participate in the learning process because they were afraid of making mistakes, and had low English proficiency, then they preferred to keep silent. Not having high self-confidence would make students quieter because they do not dare to express their ideas and rely on other students who are better and have high self-confidence.

"I don't confident to ask and answer questions. Then, I feel no need to ask and let other friends ask or answer the question. because sometimes there are questions and answers from them that are the same as mine. And when I ask and answer questions, I feel like the center of attention and it makes me uncomfortable."

The other students' responses also felt that she did not felt confident in asking and answering the question. Thus, she let their friends be more active in the class. Because if they tried to answer or ask the question in the online class it would be the center of attention and that is not comfortable. 
"... that's every time you in an online class you have different lecture but the same laptop, and yeah, that's just listening, listening, listening, that makes me sleepy."

(MP9)

The male student response above showed that he loses his motivation to join the online class because, in the online course, he just watched his monitor of the laptop, not the teacher. Thus, he preferred to keep listening to what the lecture said rather than being active during class, making him felt sleepy.

Several countermeasures are provided by the students to overcome individual factors during an online class. Focusing on the learning process, increasing self-confidence, and being well prepared are the countermeasures to solve the silencing phenomenon from individual factors. Mceown \& Takeuchi (2014) can apply a self-regulating approach that is applied purposefully by students, so they can manage the level of their motivation. If they have higher motivation, they can improve their self-confidence and they eventually become more well prepared to join the class

\section{Lecturer factor}

The next factor influencing classroom silence is the teacher factor. In classroom silence, the teacher factor has a crucial role (Zhouyuan, 2016). The participants' responses showed that they also chose the lecturer's factor as the reason why they were quieter in class. The student's statement supports this phenomenon.

"In my opinion, the lecturer is a crucial factor of why I am keeping silent during the class. I think I cannot freely express my ideas in class because the teaching method was not helping me to be engaged. I actually wanted to be active but I couldn't make it because of my perspective of some substance reasons of learning." (MP6)

"Some of the lecturers in the course, the students not obligated to answer or asking the question, so I chose to be silent."

"If we ask our friend, it will be easier to understand the material, compared to listening to the explanation from the lecturer or the teacher, because sometimes the lecturer or the teacher's explanation is too theoretical."

"...you know is too much term in the ICT, so, I tend to silent."

The male and female student's responses above showed that he was silent in the class because the lecturer's teaching method did not allow the students to participate in the class. Thus, he cannot express and deliver his ideas in class and tend to be silent in class. The other 
participants also stated that they did not understand the teacher's explanation because the lecture delivered the material too complicated.

There is also the suggestion from the male students that the lecturer should make the learning process enjoyable so that the students can enjoy and engage in the learning process.

"In my opinion, basically lecturers have to make students be interested of the course subject first and treat students as their learning partner by building the communication, not just as an information"

The student suggestion to overcome the lecturer factor indicated that the lecturer should improve their teaching method to be an innovative teaching method that makes the students more interested in the class and treats the students as their learning partner. Therefore, students could share their thoughts and enjoy teaching and learning activities during an online class. That way, the classroom becomes more fun and engaging and students will be happy to be actively involved in EFL online classroom. Zhouyuan (2016) stated that the teaching methods greatly influence the students' performance in the classroom. EFL teachers need to be creative and keep updating their knowledge, so their teaching methods will be varied and students will be more engaged to join the class.

\section{Cultural factor}

Apart from individual and lecturer factors, cultural factors were also factors causing the student silence in the classroom. The male participant's response supports this data.

"Cultural factors make me couldn't focus, such as the time duration of learning while some lecturers seem wanted to end the class immediately so that I cannot really enjoy the learning process since I saw that the lecturer is a subject and the students are just an object of learning. However, I also felt that when most students are not interested so that I felt I was not supposed to be active. I have a lot of things to say but I understand my classmates wanted the class to be ended as fast as possible."

(MP6)

The male students of English language education above showed that he could not focus in the class because of the culture that formed in the class conditions. For example, the lecturer wanted to end the class as soon as possible. This is because for some of the synchronous meetings there is an application that was only provided for 40 minutes. On the other hand, the lecturer also does not want to burden the students' internet costs for a virtual class, so he cannot enjoy the learning process. Besides, he has a lot to say in class. But he knew the feeling of his students who wanted the class to end soon. 
"The condition of the class, the other student also not active, so I chose to keep silent also.

The female students' response above showed that she kept silent during online class because she is also affected by the class's situation that is so quiet and no student engages in the class, then she also keeps silent.

The following solution is to avoid the cultural factors by having a good atmosphere such as supportive friends. Supportive friends played a crucial role in achieving an effective learning atmosphere.

"Supportive friend is a very important factor to me. I need friends who understand my vision to support in terms of the learning process. This factor is good for me to be my external support system."

The male response above showed that he needed supportive colleagues as external support. So, he can share and discuss the course. If the classmates are very supportive, it can lead to positive learning culture and that is great for English improvement.

\section{Technological factor}

The other factor that makes the student silent is the technological factor. The technological factor is the factor that comes from the technology that the students or teacher implemented during an online class. In the absence of technology, online classes will not work. However, sometimes there are problems with the use of technology used during online classes. The obstacles that could be encountered when using technology are the internet connection, the device, etc. Thus, this problem influences them to be silent students in the classroom. Because of this problem, the material given by the teacher is not understood clearly. This data is supported by the female students' statements from the interview.

"... in this online learning, sometimes there is a network problem, so I can't focus on the material present, so I'm not participating in the class ..... Also if the internet doesn't support me, so yeah I can't do anything without an internet connection. ”(FP2)

The response of the female students above showed that she had a problem with her internet connection. She does not get a clear teacher's explanation about the material, which made her keep silent in the online class. The material did not deliver clearly because of the internet connection.

Besides, some female students have the same problem with the network connection, making them remain silent in the online class. 
“The networking in my house is bad, and sometimes it doesn't support answering or being active in the class."

"Connection in my country is really really bad"

The students' responses above showed that the internet connection is not always stable. Sometimes the Wi-Fi connection is unstable, which makes her afraid that if she speaks in the online class, her voice could not be heard clearly by the lecturer and others.

The solution that was provided by the students is asking the other friends. Most of the students chose to remain silent in class because they were left behind by the material presented in the online class. Asking the other friends can make the student more understand the material left behind presented during online classes.

"Well, I'm catch up the material with asking my friend, and also read the material before the class, so I can be active. I can more active in the class like cross-checking my comprehension"

"If I lost of Google meet if I lost of online class, and after that, I will ask my friend what the teacher explain, and the teacher gives some material, like some question, some homework, yes, I will talk to my friend"

The male and female participants' responses above showed that they need to ask the material to the other friends to get a piece of in-depth information about the material delivered in the online class. By getting explanations from other students, it will make the students understand the material better. They need to ask their friends due to technological issues, such as the internet connection and unclear voice when doing a virtual class. Fortunately, they ask their classmate to know some points that they missed while joining the class. These technological issues need specific treatment, such as recording and more complete supporting materials, so, when some students missed some important information, they can just watch the recording or read the materials on their own.

\section{Domestic factor}

Finally, the factor that causes silent phenomena in an online class is the domestic factor. Domestic factors or it can be called factors that come from the environment of the students, such as conditions at home or in the family. During the Covid-19 pandemic situation, the students have online classes from their homes without going to the campus. However, the condition of the house does not completely support the student to join an online class. The home condition is not always conducive. The students' statement supports this situation. 
"... sometimes I cannot hear the voice of the teacher, and I get disturbed from voice or noise of the car and my sister and so make me can't understand the material from the teacher explaining."

The female student's response above showed that she felt disturbed because her home's condition is not conducive for online study. After all, her home is close to the highway, and there is a noisy vehicle. Thus, the sound of her sister also disturbed her when studying online at home.

The following countermeasure is by recording the class process. When joining online classes from home, several obstacles make online learning ineffective. Students' problems include the noisy background in the house. The solution given by students when facing these problems is by recording online learning activities.

"I always record the video from Google meet of the course, and after that, I will listen after that, I listen again and study it individually again"

The female's answer above showed that she chose to record the online class process when the teacher explains the material. The conditions at her house are not supportive and crowded because her home is next to the highway. Thus, if she records the learning process, she could replay or relisten the teacher's explanation. In this way, she will not lose the meeting and can understand the material given by the lecture.

\section{CONCLUSION}

Based on the finding and discussion of the research problem, this study revealed five factors causing classroom silence; individual factors, the teacher, cultural, technological, and domestic factors. To deal with the individual factor, students need to boost their motivation by applying the self-regulating approach. The second factor creating classroom silence is the teacher. Here, he needs to create teaching methods, so the online class will be more engaging and fun. The next is a cultural issue. If some students can create a positive learning culture in class, EFL learning can be more successful. The fourth one is related to technology such as bad internet connection and unclear voice while having an online class. Record the class and add more references will be a good idea to solve these issues. The last is the domestic factor. Here, students' homes were not representative enough for online classes because it is noisy and crowded. Record the teaching and learning process will make them easy to relisten when there are some points that they do not really understand. 
This research, knowing the factors that cause students to be silent in class and how to overcome the problems, hopefully, would be able to provide views and an additional reference that EFL teachers and students can refer to when they face a similar situation. So, a silent situation in virtual English class can be eliminated and EFL online learning would be engaging, fun, and interesting. As a result, the expected learning goals would be reachable through appropriate online teaching approaches.

\section{REFERENCES}

Abidah, A., Hidaayatullaah, H. N., Simamora, R. M., Fehabutar, D., \& Mutakinati, L. (2020). The impact of covid-19 to Indonesian education and its relation to the philosophy of Merdeka Belajar". Studies in Philosophy of Science and Education, 1(1), 38-49. https://doi.org/10.46627/sipose.v1i1.9

Amin, F. M., \& Sundari, H. (2020). Efl students' preferences on digital platforms during emergency remote teaching: Video conference, LMS, or messenger application? Studies in English Language and Education, 7(2), 362-378. https://doi.org/10.24815/siele.v7i2.16929

Baticulon, R. E., Alberto, N. R. I., Baron, M. B. C., Mabulay, R. E. C., Rizada, L. G. T., Sy, J. J., Tiu, C. J. S., Clarion, C. A., \& Reyes, J. C. B. (2020). Barriers to online learning in the time of COVID-19: A national survey of medical students in the Philippines. MedRxiv, 1-19. https://doi.org/10.1101/2020.07.16.20155747

Choi, J. Y. (2015). Reasons for silence: A case study of two Korean students at a U.S. graduate school. TESOL Journal, 6(3), 579-596. https://doi.org/10.1002/tesj.209

Creswell, J. W. (2003). Qualitative inquiry \& research design 3rd edition.

Gulati, A., Pomeranz, C., Qamar, Z., Thomas, S., Frisch, D., George, G., Summer, R., DeSimone, J., \& Sundaram, B. (2020). A comprehensive review of manifestations of novel coronaviruses in the context of a deadly covid-19 global pandemic. American Journal of the Medical Sciences, 360(1), 5-34. https://doi.org/10.1016/j.amjms.2020.05.006

Harumi, S. (2011). Classroom silence: Voices from Japanese EFL learners. ELT Journal, 65(3), 260-269. https://doi.org/10.1093/elt/ccq046

Juniati, S. R., Jabu, B., \& Salija, K. (2018). Students ' silence in the EFL speaking classroom. The 65th TEFLIN International Conference, July, 90-94. 
Kuama, S. (2016). Is Online Learning Suitable for All English Language Students? 52(December).

Margaret C. Harrell; Melissa A. Bradley. (2009). Data Collection Methods Semi-Structured Interviews and Focus Groups. In Distribution. www.rand.org/content/dam/rand/pubs/technical_reports/2009/RAND_TR718.pdf

Mceown, M. S., \& Takeuchi, O. (2014). Innovation in language learning and teaching motivational strategies in EFL classrooms: How do teachers impact students ' motivation? Innovation in Language Learning and Teaching, 8(1), 37-41. https://doi.org/10.1080/17501229.2012.741133

Min, H. (2016). A study on silence phenomenon in a college English classroom. International Journal of Education and Research, 4(6), 451-458.

Pranasti, B. W. (2013). Student's Silence Experience on EFL Classroom: Factors and Solutions. In universitas kristen satya wacana.

Ryan, F., Coughlan, M., \& Cronin, P. (2009). Interviewing in qualitative research: The one-toone interview. International Journal of Therapy and Rehabilitation, 16(6), 309-314. https://doi.org/10.12968/ijtr.2009.16.6.42433

Salkind, N. J. (2010). Encyclopedia of research design (Vol. 1). Sage Publications.

Starman, A. (2013). The case study as a type of qualitative research. Journal of Contemporary Educational Studies, 1(2013), 28-43.

Sun, A., \& Chen, X. (2016). Online education and its effective practice: A research review. Journal of Information Technology Education: Research, 15(2016), 157-190. https://doi.org/10.28945/3502

Van Tuyen, N. (2018). Factors that affect student reticence in class. 115(Icems 2017), 179184. https://doi.org/10.2991/icems-17.2018.35

Wang, M. (2016). Analysis of classroom silence in English class in Chinese universities. 2(1), 54-64. https://doi.org/10.25236/AJHSS.040024

Zhouyuan, Y. (2016). The analysis about the factors of silence in college English classroom. Studies in Literature and Language, 12(5), 105-110. https://doi.org/10.3968/8402 